\title{
Permanências e deslocamentos de jovens militantes de partidos políticos ${ }^{1}$
}

Ana Karina Brenner ${ }^{2}$

\section{Resumo}

Apesar da emergência de novas formas de engajamento e dos deslocamentos dos jovens para elas, há os que persistem no tradicional engajamento em partidos políticos. Aos conceitos de socialização e disposição, na busca de compreensão sobre os engajamentos, articula-se uma dimensão sincrônica, que se revela nas interações vividas pelo sujeito no presente ou no passado próximo. As redes de interação seriam os agentes da ativação e transformação das disposições em prática. As redes de sociabilidade tiveram lugar bastante central no momento da crise política produzida entre 2003 e 2005, com os casos da Reforma da Previdência e do Mensalão, que levaram à criação do PSOL a partir de militantes dissidentes do PT. A busca por coerência do comportamento militante foi determinante tanto para a permanência no partido quanto para o deslocamento para o novo partido.

Palavras-chave: Engajamento; jovens; militância partidária

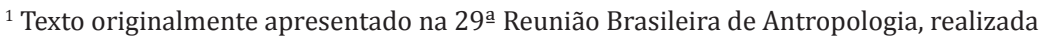
entre os dias 03 e 06 de agosto de 2014, Natal/RN

${ }^{2}$ Doutora em Educação. Professora Adjunta da UERJ - Universidade do Estado do Rio de Janeiro. E-mail: anakbrenner10@gmail.com
} 


\title{
Permanence and displacements of young activists in political parties
}

\begin{abstract}
Despite the emergence of new ways of engagement and the displacements of young people towards these new ways, there those who persist in the traditional commitment to political parties. Beyond the concepts of socialization and disposition, in the attempt to understand engagements, a synchronic dimension is joined which can be seen in the interactions experienced by the individual in the present or in the near past. The interaction networks would play the role of activating and turning dispositions into practices. The sociability networks took a very central place at the time of political crisis produced between 2003 and 2005 with the cases of the Reform of Social Security and Mensalão (an alleged scheme where Congress members would get money in exchange for political support to the Government) leading to the foundation of a new political party, PSOL - the Socialism and Freedom Party, by former activists from PT, the Workers' Party. The effort to be coherent in their behavior as an activist was determinant both for the permanence in the existing political party and for the displacement to the new political party.

Keywords: Political engagement; young people; political party activism.
\end{abstract}

Estudos recentes sobre engajamento (Cicchelli, 2009; Müxel, 2008, 2005, 2002; Estanque, 2001; Moreira, 2000; Paula, 2004; Hammes, 2005) têm demonstrado profundas transformações nas práticas de engajamento dos jovens e nos modos de construir a militância. Segundo Cicchelli (2009), construiu-se um discurso de apatia política dos jovens a partir da experiência da geração anterior para a qual a militância e o engajamento significavam estabilidade, duração e devoção a algum grupo de interesse. No entanto, as pesquisas acima referidas comprovam transformações e não apatia. 
Müxel (2008) afirma que os jovens são confrontados, ao mesmo tempo, com a necessidade de identificar-se com os adultos e de inovar e, por isso, sua relação com a política se constrói através de uma tensão identitária entre a herança e a experimentação. A herança permite identificar-se e sentir-se pertencente a algum tipo de filiação política; a experimentação permite a ruptura com padrões e modela as práticas a partir das singularidades de cada geração e de cada indivíduo. A interação entre herança e experimentação produz aprendizagens que modelam opiniões e saberes que orientam as escolhas políticas, eleitorais e partidárias.

O engajamento de jovens em partidos políticos é um fenômeno de poucos no Brasil - assim como são poucos os adultos engajados. Entre adultos chega a 10\% o número de filiados em partidos políticos e, entre jovens, não passa de 4\%, conforme dados do $\mathrm{TSE}^{3}$. Deve-se levar em conta, ainda, que o número de filiados não corresponde ao número de jovens (e adultos) que efetivamente militam em partidos, sendo este significativamente menor. 0 engajamento, diferentemente da filiação, exige um envolvimento maior, dedicação a atividades sistemáticas no cotidiano partidário, participação em reuniões, dedicação de tempo a atividades de organização, recrutamento de novos militantes, formação política, etc.

As reflexões apresentadas neste artigo se fundamentam em 21 entrevistas realizadas com jovens militantes ${ }^{4}$ de partidos políticos entre os anos de 2009 e 2010. São jovens militantes de 5 partidos, todos considerados de esquerda ${ }^{5}$.

${ }^{3}$ Dados nacionais divulgados pelo TRE de Santa Catarina. As informações datam de 28.02.2007 e foram coletadas no site www.tre-sc.gov.br/site/noticias em 20.11.2007.

${ }^{4}$ Dos 21 entrevistados 11 eram homens e 10 mulheres que são aqui apresentados com nomes fictícios.

${ }^{5}$ Ainda que os marcadores que definem tradicionalmente o que é direita e esquerda política estejam cada vez mais diluídos e pouco claros, as mais variadas definições de direita e esquerda enquadrariam os partidos nos quais militam esses jovens à esquerda, uns mais e outros menos voltados ao centro. 


\section{Jovens e engajamento na atualidade}

A partir de pesquisa realizada com jovens franceses, Cicchelli (2009) afirma que, para compreender o significado dos novos engajamentos de jovens, deve-se conhecer as experiências que estão sendo construídas por eles, além de compreender as condições sociais que fazem emergir os atuais engajamentos.

Em investigação realizada sobre a participação política de jovens franceses, Müxel, Riou e Lehay $(2005)^{6}$ afirmam que a cultura de protesto, especialmente através de petições e manifestações de rua, tem crescido na França.

A pesquisa confirma a queda da militância tradicional. Partidos políticos e sindicatos não são mais atrativos, e os jovens têm mais desconfiança sobre eles. Eles não querem ser prisioneiros de uma organização, não querem mais adotar todas as suas obrigações e objetivos políticos. Eles provavelmente querem se manter mais livres, inclusive para participar de acordo com suas próprias visões, ideias e métodos. Há certa forma de privatização da participação política. Mas isso não significa que não participem (Müxel, Riou e Lehay, 2005, p. 36)

O que parece ter mudado de fato não é o engajamento em si, mas a forma como as pessoas se conectam com essas agências de socialização e regulação. A tradicional militância estável, duradoura, quase exclusivamente dedicada a um único tema de interesse, vem sendo substituída por um engajamento mais efêmero, pontual e eletivo (Cicchelli, 2009). A presença dos jovens nas ruas, em manifestações e protestos, mostra, contudo, que estar no espaço público continua sendo uma característica marcante da juventude.

${ }^{6}$ Foram entrevistados 1010 jovens de 15 a 25 anos de idade, entre novembro e dezembro de 2004. 
Jovens são provavelmente mais parecidos com os adultos em relação à esfera política do que se possa imaginar, mas eles desenvolvem uma atitude menos conformista, mais crítica e talvez mais instrumental em relação à ela. 0 modo de engajamento dos jovens é certamente mais pragmático (Cicchelli, 2009, p. 106).

As novas formas de engajamento e mobilização, que se dirigem a interesses mais específicos e pontuais, estariam ligadas à emergência de uma nova concepção de democracia, na qual os indivíduos usam todos os meios disponíveis para obter reconhecimento de novos direitos, reforçar os já existentes e lutar por respeito social (Cicchelli, 2009).

Ainda que haja desconfiança crescente em relação à política e suas tradicionais formas de engajamento, expressas pela diminuição da presença de jovens em partidos, sindicatos e afins, a presença juvenil nestes espaços continua sendo notada. Se as clássicas formas de associação continuam a angariar jovens é porque se transformaram, deixando cada vez mais espaço para as implicações pessoais, integrando indivíduos em coletivos, mas permitindo a expressão de suas identidades.

Os estudos sobre engajamento de jovens no Brasil têm seu marco inicial nas pesquisas realizadas por Marialice Foracchi (1972, 1977, 1982), que investigou o engajamento político de jovens universitários nos movimentos estudantis nos anos 1960. 0 Estado da Arte sobre Juventude na Pós-Graduação Brasileira: Educação, Ciências Sociais e Serviço Social (1999-2006) (Sposito, 2009) mostra que os estudos sobre os engajamentos de jovens brasileiros na atualidade são poucos e referem-se, em sua grande maioria, à mobilização de jovens estudantes em espaços institucionais de participação (grêmios, centros acadêmicos, movimento estudantil). 0 balanço, que coletou teses e dissertações defendidas em todo o Brasil no período de 1999 a 2006, encontrou 35 trabalhos referidos à mobilização de jovens, estudantes ou não. Desses, 24 foram defendidos em programas da área de 
Educação, mostrando o baixo interesse das ciências sociais no tema dos engajamentos políticos de jovens no país.

\section{M ilitantismo: entre disposições e interações}

A palavra "engajamento" foi utilizada para definir um amplo espectro de fenômenos sociais. Uma de suas origens está ligada à tentativa de explicar as "linhas de comportamentos coerentes". Howard Becker (1960) buscou qualificar o "engajamento" a partir da percepção de que a noção havia sido usada por sociólogos para fins tão variados que já não permitia explicar fenômenos sociais específicos. Ainda que perceba limites em sua proposta de construção do conceito, especialmente pela falta de pesquisas empíricas sobre o tema, delineia alguns fatores primordiais para a definição do termo ${ }^{7}$. 0 "comportamento coerente" pode ser o ativador do engajamento, bem como pode ser alcançado a partir dos engajamentos. Essa coerência estaria ligada à manutenção de determinadas práticas, como no exemplo dado por Becker: a escolha de uma profissão e a sequência nela ao longo da vida. 0 "engajamento" na profissão garantiria a coerência, ou seja, manter-se na profissão inicialmente escolhida seria o elemento integrador do comportamento. Considera, no entanto, que há perdas e ganhos que devem ser levados em conta nessa escolha; mudar de profissão pode gerar desconfianças em relação às habilidades e confiabilidade do sujeito, mas manter-se em uma profissão na qual já não se satisfaz também não é coerente com a necessidade de satisfação pessoal. Por isso, as "apostas adjacentes" fazem parte do engajamento, o que significa dizer que se pode apostar em determinados ganhos colaterais que pareceriam desviar o sujeito da "linha de comportamento coerente" - a expectativa de ganhar ou de não perder motiva o en-

\footnotetext{
${ }^{7}$ Machado Pais (informação verbal, 2010) aponta que a noção de engajamento foi intensamente usada na sociologia, mas não se construiu um conceito de engajamento, como instrumento analítico.
} 
gajamento - mas, na verdade, mantém um determinado tipo de coerência ${ }^{8}$.

Para além de definir o conceito de engajamento, a sociologia busca compreender as razões e os motivos que levam um sujeito a se engajar em associações, grupos e movimentos sociais. Uma primeira tradição configurou-se em torno da construção de disposições ligadas ao conceito de habitus, de Bourdieu (1983, 1989), para quem as disposições para o engajamento político estariam ligadas às desigualdades das condições de origem e dos capitais sociais, econômicos, culturais e políticos dos agentes sociais. A posição de classe de origem e a socialização familiar e escolar, que transmite ao sujeito valores, normas e regras, configuram um conjunto de capitais que o predispõe para o engajamento político. Para Bourdieu, os sujeitos situados nas posições inferiores de classe estariam mais predispostos ao engajamento, devido à busca por diminuir a desigualdade de acessos aos bens sociais e culturais disponíveis na sociedade. 0 engajamento serviria como forma de acesso aos capitais que estão interditados a essa camada da população. Assim, o engajamento político seria uma forma de tradução subjetiva da posição de classe e origem social (Oliveira, 2005). Para Oliveira (2005), os limites dessa explicação residem no determinismo da estrutura - ao atribuir excessivo valor à posição de origem dos sujeitos -, desconsiderando a relativa autonomia de cada um em relação à sua origem e as reelaborações produzidas pelos sujeitos nestas disposições, a partir dos diversos pertencimentos sociais ao longo da vida. Outro limite da análise diacrônica do engajamento, segundo Oliveira, reside na impossibilidade de explicar de que forma tais disposições se transformam em ação efetiva em determinado momento da vida e por qual razão, dentre sujeitos que parti-

\footnotetext{
${ }^{8}$ Becker reconhece que a definição de comportamento coerente também é complexa e muitas vezes alvo de crítica. Considerando que a sociedade opera sobre um conjunto de valores minimamente conhecidos por todos, os sujeitos escolheriam alternativas consistentes com e logicamente dedutíveis deste conjunto básico de valores. A possibilidade de ganhos colaterais é que levaria a rupturas no comportamento.
} 
lham de características comuns, alguns se tornam engajados e outros se mantêm inativos.

Diante da crítica ao determinismo do habitus, Bourdieu, em suas Meditações Pascalianas (2001), revisita o conceito, introduzindo a possibilidade de um habitus clivado. As clivagens ocorrem na relação com o campo onde o sujeito se situa e as diferentes experiências que ocorrem. Bourdieu admite que as disposições podem se "desgastar" e que o habitus pode se "atualizar" na relação com um determinado campo e reconhece que, desta maneira, um mesmo habitus poderia dar origem a práticas e posições muito diferentes, de acordo com o campo em que cada sujeito se insere.

Ainda assim, para Fillieule (2001), as tensões e contradições do ator têm suas origens nas modificações que ocorrem no âmbito das práticas sociais e a reelaboração conceitual de Bourdieu ainda não consegue explicar de que forma uma disposição adquirida se transforma em ação efetiva.

A tradição sociológica do interacionismo simbólico da Escola de Chicago torna central o papel das redes de interações anteriores ao engajamento. As redes de interações estabelecidas pelo sujeito no momento presente, significando contato com espaços e grupos com os quais se identifica e é capaz de construir algum tipo de reciprocidade, é que tornariam possíveis o seu engajamento. Estaria presente, além da identificação com o grupo, um cálculo que equacionaria positivamente a relação entre o investimento realizado na militância e as compensações materiais e pessoais produzidas por ela, ou, ainda, o prestígio que poderia angariar através deste engajamento.

Os limites dessa explicação residem no fato de não se levar em conta a socialização precedente e as disposições adquiridas, tomando o momento presente como único determinante das disposições e competências necessárias para o engajamento 
(Fillieule, 2001; Mcadam e Paulsen, 1993; Oliveira, 2005). A decisão pelo engajamento estaria ligada à identificação do sujeito com determinados grupos com os quais interage no presente e as motivações se relacionariam com um cálculo utilitarista, mas também com ganhos simbólicos e afetivos. 0 conjunto de regras, normas, valores internalizados através da socialização primária e os pertencimentos sociais precedentes não estariam relacionados com a tomada de decisão de se engajar.

A clássica dicotomia que situa as razões do engajamento entre a estrutura e a estratégia - ou, dito de outra forma, entre uma análise diacrônica e outra sincrônica dos sujeitos - não dá conta da complexidade dos fenômenos sociais que produzem o engajamento e devem se articular numa nova possibilidade analítica, que permita esclarecer os modos como se constroem as disposições, competências e possibilidades de engajamento (Fillieule, 2001; Oliveira, 2005; Seidl, 2009). Tal articulação entre análise sincrônica e diacrônica também permite compreender a maneira pela qual uma disposição se transforma em ação concreta e as razões para uns se engajarem e outros não, além de perceber o que leva os sujeitos a se engajarem em um e não outro grupo (Agrikolianski, 2001). É preciso considerar um mosaico de fatores que contemplem a rede de interações do presente e os processos de socialização precedentes.

Para Klandermans (1984), o envolvimento em algum tipo de movimento seria o resultado de processos de decisão racional, através dos quais os sujeitos pesam custos e benefícios da participação (p. 583). A relação entre custos e benefícios do engajamento é fundamental para explicá-lo, mas a relação entre os sujeitos também exerce papel decisivo. Ainda segundo o autor, uma pessoa se engajará se conhecer oportunidades para fazê-lo, se for capaz de lançar mão de uma ou mais oportunidades e estiver disposta a isto. Em estudo posterior, Klandermans e Oegema (1987) afirmaram haver 4 aspectos distintos para a concretização do engajamento: (i) formação de potenciais disposições 
para o engajamento; (ii) formação e ativação de redes de mobilização; (iii) ativação das motivações para o engajamento e (iv) remoção das barreiras à participação. Os dois primeiros aspectos precisam estar presentes para que o terceiro seja ativado e, quanto mais motivado estiver o sujeito, maiores as barreiras que ele será capaz de transpor para concretizar seu engajamento.

Os mesmos autores afirmam que os movimentos sociais ou grupos precisam acessar redes para que as pessoas possam se tornar alvo do potencial mobilizador destes grupos ou movimentos. No caso do recrutamento de jovens para os partidos políticos investigados, as redes escolares e universitárias se apresentam como instâncias privilegiadas de recrutamento de militantes.

Há, contudo, outras formas privilegiadas e usuais de chegar a possíveis militantes de movimentos e grupos de engajamento, tais como mídia de massa, correspondência direta, vínculo com organizações e laços de amizade. Os dois primeiros mostram-se menos efetivos, o terceiro permite o recrutamento coletivo e os laços de amizade se mostram importantes (Klandermans e Oegema, 1987), mas, segundo McAdam (1993), foram pouco estudados. Para McAdam, as pesquisas mostram que os laços sociais são importantes para o ativismo, porém não explicam por que e como tais laços operam na realização do engajamento. Mostra, com exemplo na pesquisa de Klandermans e Oegema (1987), que há muito mais pessoas com "disposições" ao engajamento do que pessoas efetivamente engajadas. Relaciona, então, a influência de fatores estruturais para o engajamento; se não houver estruturas que exponham os sujeitos à participação (espaços, grupos organizados localizáveis), as disposições terão pouca importância porque permanecerão inativas.

McAdam e Paulsen reforçam, assim como Klandermans e Oegema, a importância dos vínculos interpessoais e a associação a outras organizações: "Redes interpessoais densas encorajam a extensão de um convite à participação e reduzem a inseguran- 
ça sobre ela" (Mcadam e Paulsen, 1993, p. 644, tradução nossa). Isso parece fato para o recrutamento realizado pelos partidos políticos no movimento estudantil: não há, necessariamente, laços interpessoais fortes, mas a rede escolar parece dar suporte e segurança aos alunos para a participação em algo que ocorre dentro do espaço escolar ou universitário.

Entretanto, ao mesmo tempo em que as redes sociais encorajam ou dão suporte ao engajamento, elas também podem operar no sentido contrário, desencorajando-o. Por estarmos envolvidos em diferentes tipos de relacionamentos - alguns pouco institucionalizados em organizações e a maioria identificada como relacionamentos interpessoais informais que envolvem uma ou mais pessoas -, é preciso levar em conta os diversos aspectos que caracterizam a vida das pessoas.

No caso dos jovens militantes de partidos políticos, um momento de crise política se mostrou bastante interessante para ilustrar como as redes de sociabilidade e amizade têm importância fundamental no processo de tomada de posição e decisão no que se refere à militância. A crise política vivida pelo PT em 2003, com a expulsão de militantes parlamentares e criação de uma nova legenda - o PSOL ${ }^{9}$ - foi, para alguns jovens militantes, um divisor de águas. As relações de amizade se somaram à reflexão sobre princípios e práticas políticas no momento da decisão sobre ficar ou sair do partido.

\section{Crise política e novo partido: permanências e deslocamentos dos jovens militantes}

Um grupo significativo de jovens petistas rompeu com o partido quando eclodiu a crise que levou a uma cisão do PT, em 2003,

\footnotetext{
${ }^{9}$ Partido Socialismo e Liberdade, criado oficialmente no TSE em 2004, mas com onda de mudanças originada ainda em 2003
} 
ou no momento de uma segunda "onda" de deslocamentos, em 2005, quando ocorreu a chamada "crise do Mensalão". Um número significativo de estudantes petistas da universidade onde militam os jovens pesquisados filiou-se ao PSOL, mudando a configuração militante desta universidade. Se até 2003 o PT agregava a grande maioria dos estudantes, a situação se inverteu a partir dessa data, passando a ser o PSOL o partido que reunia o maior número de estudantes da universidade.

A criação do novo partido, movido por uma profunda crise política do PT, fez com que seus militantes refletissem sobre seu engajamento e colocou muitos em situação de decidir se permanecia, com a intenção de "reconstruir o partido por dentro", ou se mudava para o novo, que tinha como mote reconstruir um partido nos moldes daquilo que o PT propunha em sua origem, mas que teria se perdido havia algum tempo, segundo suas análises. Há, assim, um grupo de petistas que viveu a crise e ficou no PT e um grupo de jovens que se deslocou para o novo partido.

\section{Permanecer no PT : uma decisão difícil e ref letida}

Dos 21 jovens entrevistados, três nunca deixaram de militar no PT, mas enfrentaram "a crise" e as dificuldades do debate com seus companheiros para tentar convencê-los a ficar no partido.

Todos os 3 afirmaram que em momento algum pensaram em sair do partido; tinham, segundo eles, a convicção de que o partido poderia se reerguer da crise, construindo novas práticas, readquirindo a confiança dos militantes. Cíntia afirmou que recebeu vários convites para sair do partido. Ela integrava uma das correntes que rompeu com o PT, a Democracia Socialista - DS. A corrente se dividiu, parte ficou no partido e parte participou da criação do PSOL. Dessa corrente fazia parte, entre outros, Heloísa Helena, uma das vozes públicas de crítica ao PT, que se tornou uma das lideranças do partido que se criava. A jovem afirmou que parti- 
cipou de todo o processo de discussão sobre a criação do novo partido e que "esse processo foi muito brutal", porque vivia sob a pressão da escolha: permanecer no PT significaria perder grande parte de seu grupo de militância e amizade, que estava mudando para o novo partido; sair do PT significaria deixar o partido no qual depositou tantas energias, esforços e pelo qual, apesar dos problemas, ainda alimentava admiração e respeito. Para ela, ainda que a parcela majoritária do partido o tenha levado à burocratização, ao afastamento da base de militantes e à perda de alguns princípios fundamentais, conseguiu atingir o objetivo maior de todos os militantes, que era conquistar o governo federal.

Porque hoje nós somos o governo, hoje nós temos o Presidente da República. Quer dizer, eles [que burocratizaram o partido] não erraram completamente, eles acertaram, porque hoje nós temos o presidente da república. Mas qual foi o preço que a gente pagou? 0 preço foi um distanciamento enorme do partido com a sua base partidária; foi a perda de alguns princípios que são fundamentais, por exemplo, como a reforma da previdência. Então, na verdade, nós tivemos vários embates (Cíntia, PT).

Apesar dos embates e tensões, na hora da decisão, na balança do sair ou permanecer, pesou mais a decisão de se manter onde estava.

E quando as pessoas foram, elas partiram pra esse novo formato de partido, eu fiquei... Eu não fui pro PSOL, porque aquele partido não consegue fazer a releitura do que é o PT, porque ele continua plural, ele continua um partido tático, como o PT é. A gente entende o PT como uma ferramenta política, como a maior ferramenta política de disputa de hegemonia na América Latina, porque não tem outro. Se você souber, você me conta, porque eu não sei. (Cíntia, PT)

Não interessa, aqui, fazer uma análise política sobre os caminhos trilhados pelo partido, mas compreender como os rumos 
do partido incidem sobre a prática militante dos jovens pesquisados. Importa compreender como os jovens lidaram com as tensões e quais foram os seus caminhos para a continuidade de sua militância ${ }^{10}$, num ou noutro partido.

No caso de Cíntia, entre todos os fatores que pesavam para a decisão sobre partir ou permanecer, a fidelidade a determinados princípios e práticas partidárias pesou mais do que o espírito de grupo que a unia à sua corrente. Ela avaliou que o novo partido, pela natureza de sua formação, não seria capaz de fazer a chamada "refundação do PT" e que apenas por dentro do próprio PT tal fato seria possível. A jovem tomou uma decisão política e não foi movida pela sociabilidade do grupo ao qual pertencia. Permanecer significou um recomeço no partido, porque implicava em integrar-se a um novo grupo, mas esta foi sua alternativa preferencial.

Cíntia encontrou razões suficientes para permanecer e, no seu caso, o investimento no partido pesou mais do que o grupo militante. Veremos, no caso dos jovens que mudaram, que o grupo de pares teve forte influência nessa decisão. Para Cíntia, pesou a possibilidade de continuar tentando realizar suas convicções políticas através da militância na base do partido, independente daquilo que aconteceu ou acontece nas instâncias superiores do partido.

E, na verdade, o que a gente tem, o que eu tenho, é assim... a militância, né? A minha contribuição cotidiana e pensar que, apesar de todo esse processo de esgotamento, de burocratização interna, ainda dá, ainda tem militantes e pessoas que acreditam, né? (Cíntia, PT)

\footnotetext{
${ }^{10}$ Pode haver casos de desengajamento motivados por acontecimentos como os que levaram à criação de um novo partido, mas este não foi o caso de nenhum dos jovens entrevistados. Todos decidiram permanecer ou mudar de partido, mas nenhum abandonou a militância em partido político.
} 
Julião e Núbia também militavam intensamente no PT quando ocorreram os dois movimentos de ruptura no partido, mas não viveram estas tensões de maneira tão intensa quanto Cíntia. Uma das razões para isso reside no fato de que os dois estavam engajados em correntes do partido que não fizeram parte do grupo que criou o PSOL. Cíntia esteve no "olho do furacão" e precisou deixar seu grupo de militância para se manter no partido, buscando um novo espaço de inserção; Julião e Núbia estavam em grupos que debateram os problemas, mas tiveram, desde o início, posicionamentos voltados à reconstrução interna do PT e não à fundação de uma nova legenda.

Julião disse que ficou frustrado com os caminhos trilhados pelo partido:

Teve uma fase que eu ficava mal, principalmente no início assim, em 2005, no período de início da crise eu ficava meio... porque a água virou vinho da noite pro dia. 0 que era legal de ser PTista, do nada virou... 0 vinho virou vinagre. Mas aí, depois que eu superei isso, aí... eu costumo até brincar com meus amigos que, quanto mais essa galera me odeia, mais feliz eu fico. (Julião, PT)

Julião fala da "galera" que "me odeia" devido a sua militância ter se tornado uma oposição praticamente solitária no movimento estudantil universitário. Isso ocorreu porque o PSOL arregimentou a imensa maioria dos estudantes no momento de criação do partido e mesmo nos anos seguintes. Foi possível presenciar uma plenária do congresso de estudantes da universidade em que a maioria era militante ou simpatizante do PSOL e onde Julião foi o único representante do PT a tomar a palavra para expressar sua opinião sobre o assunto em pauta. Recebeu uma sonora vaia, mas prosseguiu com seus argumentos até o fim.

Ele seguiu confiante na decisão tomada de continuar militando no PT, apesar de todas as dificuldades produzidas pelo descom- 
passo entre o que ele pensa como prática necessária e o que a direção central do partido decidiu em alguns momentos.

\begin{abstract}
Porque eu sei que eu estou afirmando a minha posição e eu tenho direito, dentro do entendimento da própria democracia. Isso é uma contradição. A democracia, ela resulta da diferença de opiniões e não do pensamento único. Eu tenho orgulho da minha trajetória, sei que eu nunca fui pelego, nunca fui o que eles [movimento estudantil] me rotulam... (Julião, PT).
\end{abstract}

A decisão de permanecer ou de sair do partido está relacionada com aquilo que Becker (1960) define como uma das características do engajamento, o comportamento coerente, já referido anteriormente. Para Becker, a coerência do comportamento estaria ligada à manutenção de determinadas práticas. Na ilustração do autor, a escolha por uma profissão e a permanência nela seriam a mostra de um comportamento coerente. No caso dos militantes, a permanência no partido também seria a mostra de um comportamento coerente em relação à escolha feita no passado, de se engajar nesse determinado partido em que está. As mudanças seriam, em uma primeira análise, resultadas de uma incoerência pouco desejável. Mas, Becker complementa que o investimento militante traz ganhos e produz apostas adjacentes, ou seja, ao se engajar em um partido político espera-se, em linhas gerais, participar de mobilizações e decisões que produzam mudanças desejadas na sociedade. De maneira adjacente, espera-se obter ganhos específicos - reconhecimento, aumento de redes de relacionamento e consequente ampliação de possibilidades de emprego, conquista de cargos nas instâncias de decisão do partido, aumento da influência política entre o grupo de pares etc. Além disso, a decisão de engajar-se em um ou outro espaço ocorre fundamentada em uma série de princípios, valores e afinidades com o espaço de engajamento e com as pessoas que coabitam este espaço. Assim, a decisão de permanecer no partido não é sinônimo imediato de "comportamento coerente" nem a decisão de mudar de partido é sinônimo de ausência de coerência. Por- 
tanto, coerente, no caso dos partidos, é fazer aquilo que mantém o jovem no caminho de suas apostas e que garante a permanência de seus princípios e valores. Não há, portanto, uma equação precisa para definir o que é coerente e o que não é.

Becker considera que há perdas e ganhos que devem ser levados em conta na escolha das mudanças ou permanências. Mudar de profissão, no exemplo do autor, pode gerar desconfianças em relação às habilidades e confiabilidade do sujeito, mas manter-se em uma profissão na qual já não se satisfaz também não é coerente com a necessidade de satisfação pessoal. Transportando o exemplo para os partidos, mudar pode gerar desconfianças em relação aos valores políticos defendidos, mas manter-se em um lugar onde já não se tem mais confiança de alcançar objetivos coletivamente elaborados não é coerente com o próprio princípio da militância partidária.

Os jovens que decidiram manter-se filiados refletiram que suas apostas de construir um partido que lutasse por mudanças e justiças sociais continuavam direcionadas ao PT, que, apesar dos problemas, ainda era possível alcançar estes objetivos. Também consideravam que, na medida em que tinham investido tanto do seu tempo e suas energias nesse partido, era coerente manter esse investimento, pois, do contrário, pareceria um investimento realizado em vão, jogado fora.

\section{A ruptura com o PT : um difícil processo}

Foram cinco os jovens pesquisados que, inicialmente filiados ao PT, romperam e se filiaram ao PSOL, alguns no primeiro momento de cisão do PT, em 2003, outros apenas depois da "crise do Mensalão", em 2005.

Ademir, Silvano e Luciano iniciaram sua militância no ensino fundamental (os dois primeiros) e no médio (o último) e já eram 
considerados "quadros" do partido, porque se envolveram intensamente no movimento estudantil, estiveram à frente de realizações significativas para o movimento no estado do Rio de Janeiro e um deles - Luciano - foi um militante profissional ${ }^{11}$ durante algum tempo. Todos tinham percursos militantes longevos. Cláudio e Norberto eram militantes mais recentes do PT, ainda assim com percursos longos, mas menos intensos quando a crise se instalou, em 2003. Ademir, Luciano, Norberto e Cláudio eram todos da mesma corrente do PT, a DS (Democracia Socialista), da qual parte dos integrantes rompeu e parte permaneceu no $\mathrm{PT}^{12}$. Silvano estava ligado à CST (Corrente Socialista dos Trabalhadores), que mudou integralmente para o PSOL. Para os quatro primeiros jovens, a ideia de ruptura com o partido chegou mais tardiamente e três deles mudaram de partido apenas depois da crise política do Mensalão. Silvano relatou que, ainda durante a campanha presidencial de Lula em 2002, quando foi lançada a "Carta ao Povo Brasileiro", os integrantes de sua corrente começaram a afirmar que, em algum momento, haveria uma ruptura drástica com o partido. Silvano disse que só não esperava que o processo se desencadeasse tão rapidamente.

Eu não esperava que nos primeiros meses de governo ia ser tão forte, tão rápido. E isso pra mim me assustou, me assustei bastante. Por exemplo, o governo do Lula começou em 2003, quando foi em 19 de janeiro de 2004 nós estávamos discutindo um movimento pra um novo Partido. Foi a primeira reunião, onde participaram quarenta pessoas aqui no Rio de Janeiro e eu estava. Foi quando a Heloísa Helena se decidiu, porque naquela época criou muita confusão se tinha que se criar um Partido ou não (Silvano, PSOL)

Os integrantes de sua corrente se desfiliaram do PT em bloco, assim que foi decidida a criação de uma nova legenda - discutia-

\footnotetext{
${ }^{11}$ Recebeu recursos do partido, durante um determinado tempo, para que se mantivesse financeiramente e se dedicasse a organizar o movimento estudantil em nome do partido. 12 Já foi citado o caso de Cíntia, que, também da DS, não mudou de partido.
} 
-se a possibilidade de os expulsos do PT aderirem a alguma outra legenda já existente, proposta que acabou sendo rechaçada. Houve menos tensionamentos na saída de Silvano do partido, porque os companheiros de militância cotidiana foram todos para o novo partido e, com os militantes que ficaram no PT, tinha menos proximidade e afinidade. A própria decisão de sair do partido foi em grande medida facilitada pela ausência de conflitos referidos às redes de sociabilidade partidária - todos os colegas, companheiros, amigos de militância seguiam o mesmo caminho. Isso tornava a decisão de mudar de partido bastante óbvia, quase natural.

No caso dos outros quatro jovens, que saíram de uma corrente que se fragmentou, cada um teve que tomar sua decisão individualmente ou junto a seus pequenos grupos e núcleos de militantes; não foi uma decisão coletivamente assumida por toda a corrente. E cada decisão foi comunicada separadamente ao partido. Alguns comunicaram sua decisão de desfiliação em reuniões do partido, outros o fizeram por documento escrito. Ademir disse que o processo de tomada de decisão foi muito desgastante, que havia muita pressão entre os companheiros de militância - tanto dos que tinham decidido ficar quanto dos que tinham decidido sair do PT. O jovem afirmou que alguns ex-companheiros avaliaram a saída do partido como uma traição, não apenas política, mas pessoal. Alguns deixaram de se falar. Ser taxado de traidor e ver antigos companheiros não lhes dirigir mais a palavra foi experiência comum aos quatro jovens, em maior ou menor grau, depois da saída do PT e filiação ao PSOL.

Cláudio foi o que relatou problemas mais sérios com amigos que ficaram no PT, afirmando que a ruptura foi de tal maneira tensa que chegou às raias da justiça.

Foi muito difícil (...) um dos meus melhores amigos, na verdade, ficou [no PT], se tornou um dos principais dirigentes e está na DS hoje... no processo de ruptura, em que se va- 
lorizou aspectos do caráter dele e que nunca tinham sido valorizados. Entrou na justiça pessoalmente contra mim e contra o fulano, outro companheiro. Porque, na verdade, na eleição (...) estava todo mundo junto no DCE e, quando a DS rompe, tem uma eleição logo em seguida. Então, a gente sai em chapas separadas, mas chegou a ter agressões, roubos de urnas, coisas assim que tinham passado de qualquer limite. E colocaram um processo na justiça contra nós, fizeram um tipo de enfrentamento muito, muito duro mesmo. Hoje em dia, a gente nem se fala mais, nem se cumprimenta. Então, muita gente ficou pelo caminho. Outros não, outros que eram menos próximos e que atuaram de maneira menos firme pra nos combater, até hoje eu consigo ter relação tranquila. (Cláudio, PSOL)

Tanto Ademir quanto Luciano só saíram do PT em 2005 (entre meados e final do ano). Para ambos, a crise do Mensalão foi a "gota d'água", o que permitiu a decisão definitiva sobre seus rumos militantes. Luciano também esperou algum tempo, desde a criação do PSOL, para compreender como o partido se constituiria, quais as suas pautas, objetivos e linhas de ação. Também aqui se evidencia uma reflexão do jovem sobre a direção de seu investimento militante. Assim como Cíntia, que optou por não sair do PT e o fez de maneira bastante refletida, Luciano também tomou distância do problema, do ponto de vista da sociabilidade partidária, e refletiu politicamente sobre os caminhos possíveis e, dentre eles, qual seria o melhor, a fim de respeitar suas convicções.

Ia ter um processo de congresso interno do PT que começou em agosto e terminou, se eu não me engano, em setembro ou outubro de 2005; pós-escândalo do mensalão, já pós-Reforma da Previdência, pós-destituição dos quatro parlamentares. É... eu achava importante participar desse processo, eu acho que seria o último marco que eu acho que deveria participar por um lado, e do outro lado, é, eu achava que precisava ficar mais claro o que que seria esse PSOL, o que seria esse novo partido (...) embora seja um partido muito pequeno, mas se ia ser um esboço de um novo partido que quisesse ser um partido de esquerda, mas sem grande 
capacidade e influência social ou um partido que tentasse, né, ou pelo menos achasse importante ter uma influência um pouco maior na sociedade(...) um partido que tivesse inserção social, onde os trabalhadores fizessem parte (...) E foi esse meu tempo de espera. (Luciano, PSOL)

Não interessava ao jovem trocar o certo pelo duvidoso, ou seja, por mais problemas que o PT estivesse enfrentando, era o partido no qual ele havia se tornado militante, conhecia os meandros de seu funcionamento e também os caminhos e espaços para discussão e busca de soluções no interior do partido. 0 novo partido poderia repetir os mesmos erros do PT, mas, sendo novo, também poderia trazer novos tipos de dificuldades para o debate interno. Por isso, Luciano observou e decidiu cuidadosamente sobre sua filiação ao novo partido.

O modo como Luciano administrou suas escolhas também é reflexo de um comportamento coerente. 0 jovem avaliou ganhos e perdas dos dois caminhos possíveis: permanecer no PT ou filiar-se ao PSOL; avaliou se a promessa do PSOL, de representar um partido com novas práticas, realmente se concretizaria; e avaliou o peso do investimento já feito no PT para saber se valeria a pena deixar tudo para trás e recomeçar em uma nova legenda partidária. Recomeçar, na balança de Luciano, pesou mais.

Ademir disse que viu razões ainda antes de 2005 para sair do partido, mas que todos os acontecimentos anteriores podiam ser justificados racionalmente. "A ruptura passional [eu] era capaz de fazer em qualquer momento, desde 98, mas pega meia dúzia de textos, lê e explica [as razões das escolhas do partido]". O desgaste político e a frustração produzidos pelo Mensalão, contudo, teriam acabado com qualquer possibilidade de justificativa racional ou passional. Foi então que decidiu pela mudança de partido.

O jovem reafirma, contudo, que a saída do PT foi a decisão que ele considerou mais acertada. Conversou com seus companhei- 
ros e se aconselhou com o pai, que não saiu do PT, mas teria ajudado Ademir a compreender a crise e avaliar razões e benefícios da escolha de ficar ou sair. Na balança de Ademir pesaram, ainda, além daquilo que já foi apontado para Luciano, os valores e práticas familiares, visto que seu pai era um militante histórico do partido. Ainda assim, a decisão pela desfiliação do PT teve peso maior e o jovem se filiou ao PSOL. Nesse caso, o fato da maior parte do grupo de militância ter mudado de partido pesou mais do que a herança e as práticas familiares.

Cláudio também saiu do PT no final de 2005, mas o momento de sua saída foi marcado mais por decisões estratégicas do seu grupo político e menos pela dinâmica do PT; ou seja, o grupo da DS ao qual estava vinculado decidiu deixar o partido no início de 2005, mas ele, que já era assessor parlamentar de um vereador do PT, deveria continuar para ajudar na transição deste vereador para o PSOL. 0 grupo achou mais estratégico fazer uma transição, ao invés de um rompimento abrupto. Com isso, o vereador conseguiria encerrar algumas atividades importantes, dando fim a seu período de permanência no PT com tranquilidade e sem tantos tensionamentos quanto os que seriam provocados por uma ruptura no começo daquele ano. 0 vereador era um independente ${ }^{13}$ no PT e continuou independente no PSOL, por isto a transição era possível; sem vínculos com correntes, o vereador podia tomar decisões em tempos diferentes. Por ser assessor parlamentar, o grupo de discussão no qual Cláudio se inseria para decidir pela mudança ou não de partido era diferente dos espaços de decisão de Ademir, Luciano, Norberto e Silvano ${ }^{14}$. Os quatro jovens situavam seus debates no âmbito do movimento estudantil e Cláudio o situava entre os grupos de apoio do mandato do vereador.

\footnotetext{
${ }^{13}$ Mandato independente ou militante independente em partidos como o PSOL e o PT são aqueles que não se vinculam a qualquer corrente do partido. Nos registros de militantes dos partidos, há sempre a divisão desses por suas correntes e um grupo definido como "independente", que não pertence a qualquer das correntes partidárias.

${ }^{14}$ Todos eles tinham no movimento estudantil seu principal espaço de militância no momento da mudança de partido.
} 
O momento de decidir a mudança de partido é diferente em cada caso e a decisão é mais individual ou mais coletiva também conforme o caso, mas a vontade dos sujeitos sempre teve peso preponderante na decisão. Todos os jovens que mudaram de partido fizeram escolhas por partidos que mais bem atendessem aos seus anseios, pelos quais se sentissem mais acolhidos e mais confortáveis em relação às práticas partidárias e pelos quais o ajuste entre os valores do partido e os valores pessoais fosse mais fino. A adesão a uma decisão coletiva só ocorreu quando havia também uma adesão pessoal às razões que justificavam a mudança.

\section{Considerações Finais}

As experimentações são a marca dos novos modos de fazer política (Müxel, 2003); a ausência de nítidos marcadores ideológicos, em oposição à sua presença nas gerações anteriores, seria a razão de tal experimentação. Também concorreria para a experimentação a mudança dos modos de se engajar. Se para as gerações anteriores o engajamento significava permanência e devoção (Cicchelli, 2009) para as atuais gerações o engajamento seria algo mais fluído, que não implicaria adotar todas as obrigações e objetivos políticos da organização, a qual haveria espaço para negociar posições intermediárias entre as consolidadas do partido e as dos jovens. "Eles provavelmente querem se manter mais livres, inclusive para participar de acordo com suas próprias visões, ideias e métodos" (Müxel, Riou e Lehay, 2005, p. 36, tradução nossa).

No caso dos jovens que mudaram de partido, a noção de experimentação se aplica, mas produzida por uma crise política que provocou nos militantes reflexões sobre princípios e práticas partidárias. Tais reflexões ocorreram fortemente influenciadas pelas redes de amizade e sociabilidade militantes. As opiniões e posições dos companheiros mais próximos de militância tive- 
ram peso significativo nas escolhas, ainda que tivessem sempre sido confrontadas ou mediadas pelos princípios e crenças pessoais dos jovens militantes. Na balança da decisão sobre ficar ou sair do PT e filiar-se ao PSOL pesou, de um lado, a posição do grupo de pares e, de outro, as convicções e crenças pessoais. Para alguns, contudo, ambas estiveram do mesmo lado.

\section{Ref erências Bibliográficas}

AGRIKOLIANSKY, E. Carrières militantes, et vocation à la morale: les militants de la Ligue des droits de l'homme dans les années 1980. Revue française de science politique, Année 2001, Volume 51, Numéro 1. pp. 27 - 46

BECKER, H. Notes on the Concept of Commitment. The American Journal of Sociology, Vol. 66, No. 1 (Jul., 1960), pp. 32-40. The University of Chicago Press. Extraído de http://www.jstor.org/stable/2773219

BOURDIEU, P. O Poder Simbólico. Rio de Janeiro: Bertrand/ Difel, 1989.

Questões de Sociologia. Rio de Janeiro: Marco Zero, 1983.

. Meditações Pascalianas. Tradução Sérgio Miceli. Rio de Janeiro: Bertrand Brasil, 2001.

CICCHELLI, V. The Contemporary Engagement of young people in France: normative injunctions, institutional programas and the multiplying forms of grouping. Italian Journal of Sociology of Education, 2, 2009.

ESTANQUE, E. e NUNES, J. A. A universidade perante a transformação social e as orientações dos estudantes: 0 caso da Universidade de Coimbra. Universidade do Minho: Braga, 2001.

FILLIEULE, O. Propositions pour une analyse processuelle de l'engagement individuel. Revue française de science politique, Année 2001, Volume 51, Numéro 1. pp. 199 - 215

FORACCHI, Marialice. A juventude na sociedade moderna. São Paulo: Pioneira, 1972

0 estudante e a transformação da sociedade brasileira. São Paulo: Companhia Editora Nacional, 1977.

. A participação social dos excluídos. São Paulo: Hucitec, 1982. 
HAMMES, L. J. Aprendizados de convivência e a formação de capital social: um estudo sobre grupos juvenis. 2005. Tese (Doutorado em Educação) - Universidade do Vale do Rio dos Sinos, São Leopoldo, 2005.

KLANDERMANS, B. Mobilization and participation: social-psychological expansions of resource mobilizations theory. American Sociological Review, Washington, v. 49, pp. 583-600, out. 1984.

; OEGEMA, D. Potencials, networks, motivations and barriers: steps towards participation in social movements. American Sociological Review, Washington, v. 52, n. , pp.519-531, ago. 1987.

McADAM, D.; PAULSEN, R. Specifying the relationship between Social Network and Activism. The American Journal Of Sociology, Chicago, v. 99, n. 3, pp.640-667, nov. 1993.

MOREIRA, M. A. Grêmios estudantis: contestação e distinção social. 2000. Dissertação (Mestrado em Educação) - Universidade Federal do Rio de Janeiro, Rio de Janeiro, 2000.

MÜXEL, A. Continuidades y rupturas de la experiencia política juvenil. Revista de Estudios de Juventud. Junio, no 81, 2008. pp. 31-44.

La participation politique des jeunes: soubresauts, fractures et ajustements. Revue française de science politique. Volume 52, Numéro 5, 2002. pp. $521-544$

; RIOU, Cécile; LEHAY, Viviane. Political Participation of Young People in Europe - Development of Indicators for Comparative Research in the European Union (EUYOUPART) WP8/ D15. National Report: France. FNSP (Fondation Nationale des Sciences Politiques) - CEVIPOF, March/ 2005.

OLIVEIRA, W. J. Paixão pela Natureza. Atuação profissional e participação na defesa de causas ambientais no Rio Grande do Sul entre 1970 e início dos anos 2000. Tese (Doutorado em Antropologia - UFRGS), 2005.

SEIDL, E. Disposições a militar e lógica de investimentos militantes. Pro-Posições, Campinas, maio/ago. 2009. Vol. 20, no 2, pp. 21-39.

SPOSITO, M. P. (Coord.) 0 Estado da Arte sobre juventude na pós-graduação brasileira: Educação, Ciências Sociais e Serviço Social (1999-2006). Belo Horizonte: Argvmentvm, 2009. 2 v. Disponível em: www.observatoriojovem.org

Recebido em 15/12/2015

Aprovado em 30/12/2015 
